\title{
Salt-Lick-Induced Soil Disturbance in the Teton Wilderness, USA
}

\author{
D. K. Walters ${ }^{1}$ and T. H. DeLuca ${ }^{2}$ \\ Authors are ${ }^{1}$ Hydrologist, Apache-Sitgreaves National Forest, 30 South Chiracahua Drive, Springerville, AZ 85938; and ${ }^{2}$ Senior Forest Ecologist, The \\ Wilderness Society, 503 West Mendenhall, Bozeman, MT 59715.
}

\begin{abstract}
Manmade salt licks on public lands throughout the Rocky Mountain West have been created to attract large game for hunting purposes. This practice is both illegal and controversial, but is of particular importance in otherwise pristine wilderness landscapes. The impact of widespread saltlicks on public lands has never been quantified. This study was undertaken to examine the degree of change in soil physical and chemical properties caused by approximately 10-60 years of salt application in the Teton Wilderness of Wyoming, USA. A total of 27 sites were identified, surveyed, and paired with non-salt-affected control areas. Three replicate sampling points were located within each salt site and in each of the paired control areas. Soil samples from each site were analyzed for soil bulk density, soil salinity as electrical conductance (EC), pH, organic matter content, sodium absorption ratio (SAR), and exchangeable concentrations of sodium $\left(\mathrm{Na}^{+}\right)$, potassium $\left(\mathrm{K}^{+}\right)$, calcium $\left(\mathrm{Ca}{ }^{2+}\right)$, and magnesium $\left(\mathrm{Mg}^{2+}\right)$. Salt-treated site centers were found to have elevated EC, bulk density, $\mathrm{pH}, \mathrm{SAR}$, and $\mathrm{Na}^{+}$concentration compared to the no-salt controls. Salt-affected sites also contained decreased organic matter contents and decreased concentrations of $\mathrm{Ca}^{2+}$ and $\mathrm{Mg}^{2+}$. Observed differences were due to the addition of $\mathrm{Na}^{+}$to the soil solum as well as direct effects of ungulates. Soil compaction appears to have a greater impact on plant establishment than the actual presence of $\mathrm{NaCl}$. Salt licks established in wilderness areas habituate animals to localized zones causing extensive soil trampling and consumption of surface soils by grazing ungulates.
\end{abstract}

\section{Resumen}

Los saladeros construidos por el hombre en a través del oeste de las Montañas Rocallosas han sido creados para atraer a la fauna silvestre mayor con propósitos de caza. Esta práctica es ilegal y controversial, pero es de particular importancia en los parajes silvestres no alterados y el impacto de los saladeros distribuidos en los terrenos públicos nunca ha sido cuantificado. Este estudio se realizó para examinar el grado de cambio de las propiedades físicas y químicas del suelo causadas por el uso de sal por aproximadamente 10-60 años en el área silvestre de Teton, Wyoming, E.U.A. Se identificaron un total de 27 sitios, los cuales se muestrearon en forma apareada con sitios no afectados por sal que sirvieron de control. En cada sitio afectado por sal y control se localizaron tres puntos de muestreo que fueron las repeticiones. Se analizaron muestras suelo de cada sitio para determinar la densidad aparente, salinidad, conductividad eléctrica (EC), pH, contenido de materia orgánica, relación de absorción de sodio (SAR), y las concentraciones intercambiables de sodio $\left(\mathrm{Na}^{+}\right)$, potasio $\left(\mathrm{K}^{+}\right)$, calcio $\left(\mathrm{Ca}^{2+}\right)$ y magnesio $\left(\mathrm{Mg}^{2+}\right)$. Los sitios que recibieron sal tuvieron una mayor EC, densidad aparente, $\mathrm{pH}$, SAR y Na${ }^{+}$que los sitios no salinos (control). Los sitios afectados por sal también presentaron menos materia orgánica y concentraciones más bajas de $\mathrm{Ca}^{2+} \mathrm{y} \mathrm{Mg}^{2+}$. Las diferencias observadas se debieron a la adición de $\mathrm{Na}^{+}$al solum del suelo, así como por efectos directos de los ungulados. La compactación del suelo parece tener un mayor impacto en el establecimiento de las plantas que la presencia actual de $\mathrm{NaCl}$. Los saladeros establecidos en las áreas silvestres habitúan a los animales a zonas localizadas, causando un pisoteo excesivo y el consumo de la superficie del suelo por los ungulados en apacentamiento.

Key Words: salinization, wilderness, salting, game management, soil degradation

\section{INTRODUCTION}

The creation of artificial salt licks for hunting in wilderness and protected areas in the Rocky Mountains has caused significant public concern. Salt licks are illegally deposited on state and federal lands by individuals to habituate elk and other game species to given locations. The actual impact of widespread saltlicks on public lands has not been quantified. This controversial issue is acutely evident in the Teton Wilderness Area (Wyoming, USA) where artificial salt licks have been created over the last 60 years to attract large game out of Yellowstone National Park for hunting purposes. Wilderness is

Correspondence: Thomas H. DeLuca, The Wilderness Society, 503 West Mendenhall, Bozeman, MT 59715. Email: tom_deluca@tws.org

Manuscript received 15 December 2006; manuscript accepted 30 August 2007. an area of undeveloped federal land that appears "to have been affected primarily by the forces of nature, with the imprints of man's work substantially unnoticeable" (Wilderness Act of 1964, 3 September 1964, P.L 88-577, 16 USC 1131-1136). The impact of the application of salt to these landscapes has the potential to negatively affect soil and plant communities; however, such impacts have never been evaluated.

Sodium $\left(\mathrm{Na}^{+}\right)$is the dominant cation present in both natural and artificial salt licks intended to attract grazing ungulates (Jones and Hanson 1985). Potassium $\left(\mathrm{K}^{+}\right)$in spring forage and the succulent condition of vegetation creates a diarrheic condition that attracts ungulates to salt sites in search of $\mathrm{Na}^{+}$ (Weeks 1974). One of the negative effects of $\mathrm{Na}^{+}$-based salt placement is the potential creation of salinized soils. Soil salinity is quantified in terms of the total concentration of soluble salts (Rhoades 1996) and is a condition that greatly 
limits soil productivity. The accumulation of soluble salts in the soil profile restricts plant growth through the increase of osmotic potential of soil solution and induction of specific ion toxicities of nutrient imbalances (Bresler et al. 1982).

Soil physical and biological properties are also negatively affected by the application of $\mathrm{Na}^{+}$salts to soils. Some impaired soil properties include swelling and dispersion of clays, reduced aggregate stability, reduced hydraulic conductivity, and reduced microbial activity including mycorrhizal infection rates (Zahow and Amrhein 1992; Barzegar et al. 1996; Juniper and Abbott 2006). These processes in turn reduce root elongation, water infiltration, soil aeration, and plant growth. Trampling by ungulates congregating at salt licks causes soil compaction, further degrading soil physical properties and reducing plant growth and establishment (Greene et al. 1994).

The USDA has developed indices of saline and sodic soils as guidelines for crop production (Richards 1954). Soils may be classified as saline, saline-sodic, or sodic based on relative measures of electrical conductivity (EC), sodium absorption ratio (SAR), and soil pH of salt-affected soils (Rhoades 1996; Rhoades et al. 1999). Although these indices were developed for agricultural purposes, they provide a benchmark from which to judge the salinity and sodicity of undisturbed or wilderness area soils as affected by the placement of salt licks.

Degradation of soil resources has direct long-term implications for natural ecosystem function including nutrient transformation, water infiltration, and plant productivity. Wilderness landscapes are to be managed as pristine, natural ecosystems, thus the degradation of soil as a result of illegal salt lick placement is of great importance to those that manage natural landscapes. To date there have been no published studies that evaluate how salt licks placed in otherwise pristine landscapes affect the soil resources or degrade the ecosystem. The purpose of this exploratory study was to evaluate the degree to which placement of artificial salt licks in the Teton Wilderness Area have influenced soil chemical and physical condition and thus aid land managers in making restoration decisions regarding salt-affected sites.

\section{MATERIALS AND METHODS}

Laboratory and field measurements were performed on soil samples collected from salt-affected sites in the Teton Wilderness during the 2000 and 2001 field seasons. These sites were located just south of Yellowstone National Park in the Washakie and Absaroka Mountain Ranges. Valley soils were formed in glacial till deposits and the upland sites formed in volcanic conglomerate residuum. Elevation for salt sites ranged from 2393 to $2915 \mathrm{~m}$. Mean annual temperature is $2.4^{\circ} \mathrm{C}$, and average precipitation is $526 \mathrm{~mm}$ annually.

A total of 27 sites across the Teton Wilderness that had been treated with salt anywhere from 10 to 60 years were identified and delineated for total area and depth of disturbance. Because of the fact that salt application for game management is illegal in the state of Wyoming, there is no record of the amount or timing of salting that has taken place. Local game managers estimate salt placement to have occurred in the past 60 years, with some occurring as recently as the last decade.
Salt-affected areas were delineated by measuring elevated soil $\mathrm{EC}$ at each site and determining the zone bare of vegetation. Vegetative cover averaged less than $1 \%$ across all sites. Sites were then measured for their total area and depth of soil disturbance by measuring the nonvegetated area. EC was screened in the field by using a 10:1 water:soil $(5 \mathrm{~g}$ soil in $50 \mathrm{~mL}$ distilled water) slurry that was equilibrated for 10 minutes prior to measurement (Rhoades 1996) on a handheld digital meter (CON 5 Acorn EC Meter; Oakton Instruments, Vernon Hills, IL). Because of the remote location of the sites, we used a dilute soil slurry rather than a saturated paste. The slurry equilibrates more rapidly and provides more reliable results for comparative measures of the degree of salinization (Sonnevelt and van der Ende 1971).

At each site three experimental sample points were located inside of the affected area and three unaffected control sample points were located $10 \mathrm{~m}$ outside of the salt area in undisturbed soil and vegetation. The three experimental points were oriented on a North-South axis through the measured center of the salt site. One sample was at the site center, and the other two were half way from the center to the edge of the affected area. The three control points were located $10 \mathrm{~m}$ away from the edge of the disturbed site, at $120^{\circ}$ angles from the center. One was at $120^{\circ}$, another at $240^{\circ}$, and the final at $360^{\circ}$. Six soil bulk density core samples (three salt and three control) were collected at a depth of $10-15 \mathrm{~cm}$ at each site (with the exception of three sites where only one salt-affected and one control sample were taken, discussed below) to create a total of 150 samples. Soil samples were packed out of the wilderness and returned to the laboratory for analysis. Each sample was analyzed separately and treated as a subsample from each site.

Soil bulk density was measured using a slide hammer core method (Culley 1993). Briefly, intact core samples $\left(103 \mathrm{~cm}^{3}\right.$ volume) were dried for 48 hours at $80^{\circ} \mathrm{C}$, cooled, and weighed. Bulk density was calculated by dividing mass by volume of the sample. These samples were then sieved to $2 \mathrm{~mm}$ and analyzed for $\mathrm{pH}$, soil organic matter content, and exchangeable $\mathrm{Na}^{+}$, $\mathrm{Ca}^{2+}, \mathrm{K}^{+}$, and $\mathrm{Mg}^{2+}$. Soil $\mathrm{pH}$ was measured in a $1: 2$ soil to $0.01 \mathrm{M} \mathrm{CaCl} 2$ suspension using a glass electrode (Thomas 1996). Exchangeable $\mathrm{Na}^{+}, \mathrm{Ca}^{2+}, \mathrm{K}^{+}$, and $\mathrm{Mg}^{2+}$ were extracted by shaking $10 \mathrm{~g}$ of soil in $35 \mathrm{~mL}$ of $1.0 \mathrm{M} \mathrm{NH}_{4} \mathrm{Cl}$ for 1 hour and then filtering the extracts through a Whatmann- 42 filter paper. The extracts were analyzed for cation concentration on an atomic absorption spectrophotometer (Rhoades 1996). The SAR was calculated to assess the degree of sodicity (Rhoades et al. 1999) using the following equation: $\mathrm{SAR}=\left[\mathrm{Na}^{+}\right] /$ $\left[\left(\mathrm{Ca}^{2+}+\mathrm{Mg}^{2+}\right)\right] 0.5$, where concentrations are in meq / $\mathrm{L}$ (Janzen 1993). Soil organic matter was estimated by loss of mass on ignition at $440^{\circ} \mathrm{C}$ (Kalra and Manynard 1991).

Data from all sites were analyzed for their distribution and homogeneity of variance. Summary statistics were calculated on all sites $(n=3)$ with the exception of sites 8,9 , and 12 , which had only one sample per site. The replicate data points were averaged for the individual sites and treated as an independent observation which was then averaged across all 27 sites to contrast all salt-affected soils versus undisturbed soils using a paired $t$ test. The salt-affected soil and undisturbed soil are considered to be of the same soil origin prior to the placement of the salt licks (Sokal and Rohlf 1981). 
Table 1. General characteristics of site and soils for 27 salt-affected sites in the Teton Wilderness Area.

\begin{tabular}{|c|c|c|c|c|c|c|}
\hline Site & Elevation (m) & $\%$ slope & Habitat & Sand $\left(\mathrm{g} \mathrm{kg}^{-1}\right)$ & Clay $\left(\mathrm{g} \mathrm{kg}^{-1}\right)$ & Great group \\
\hline 1 & 2393 & 0 & Meadow & 20 & 560 & Haplocryolls \\
\hline 2 & 2396 & 0 & Meadow & 200 & 500 & Haplocryolls \\
\hline 3 & 2421 & 0 & Meadow & 100 & 360 & Haplocryolls \\
\hline 4 & 2409 & 0 & Meadow & 640 & 200 & Haplocryolls \\
\hline 5 & 2405 & 5 & Meadow & 620 & 220 & Cryochrepts \\
\hline 6 & 2457 & 20 & Meadow & 420 & 240 & Haplocryolls \\
\hline 7 & 2409 & 0 & Meadow & 260 & 360 & Haplocryolls \\
\hline 8 & 2409 & 0 & Forest & 420 & 380 & Cryochrepts \\
\hline 9 & 2817 & 5 & Alpine Meadow & 380 & 380 & Cryochrepts \\
\hline 10 & 2817 & 0 & Alpine Meadow & $N A$ & & Medisaprists \\
\hline 11 & 2561 & 0 & Meadow & 600 & 200 & Cryochrepts \\
\hline 12 & 2436 & 10 & Meadow & 420 & 260 & Haplocryolls \\
\hline 13 & 2424 & 0 & Meadow & 760 & 120 & Haplocryolls \\
\hline 14 & 2482 & 0 & Forest & 440 & 280 & Cryochrepts \\
\hline 15 & 2561 & 0 & Forest & 340 & 340 & Cryochrepts \\
\hline 16 & 2555 & 15 & Meadow & 260 & 400 & Cryochrepts \\
\hline 17 & 2710 & 15 & Forest & 180 & 380 & Cryochrepts \\
\hline 18 & 2707 & 0 & Meadow & 320 & 400 & Cryochrepts \\
\hline 19 & 2790 & 25 & Alpine meadow & 400 & 380 & Cryochrepts \\
\hline 20 & 2790 & 25 & Alpine meadow & 500 & 340 & Cryochrepts \\
\hline 21 & 2915 & 15 & Forest & 350 & 430 & Cryochrepts \\
\hline 22 & 2768 & 0 & Alpine meadow & 380 & 440 & Cryochrepts \\
\hline 23 & 2805 & 0 & Alpine meadow & 40 & 430 & Cryochrepts \\
\hline 24 & 2671 & 0 & Meadow & 420 & 360 & Cryochrepts \\
\hline 25 & 2683 & 0 & Meadow & 290 & 390 & Cryochrepts \\
\hline 26 & 2823 & 5 & Alpine meadow & 490 & 410 & Cryochrepts \\
\hline 27 & 2820 & 0 & Alpine meadow & 510 & 350 & Cryochrepts \\
\hline
\end{tabular}

\section{RESULTS AND DISCUSSION}

A total of 27 salt sites were studied across the Teton Wilderness Area, all of which had less than $1 \%$ vegetative cover. Table 1 provides general characteristics of the 27 sampled sites including elevation, aspect, percent slope, habitat, texture, and soil great group. The estimated area of each site varied from 657 to $20 \mathrm{~m}^{2}$ and varied from $65 \mathrm{~cm}$ deep to little or no depression. The placement of salt licks on these lands has resulted in the formation of over $5680 \mathrm{~m}^{2}$ of barren soil patches spread across otherwise pristine wilderness landscapes.

Salt lick sites soils had elevated salinity compared to native soils (Table 2). Using a coarse conversion factor $(15 \times$ EC10:1) to adjust EC in the $10: 1$ slurry to that in a saturated paste indicates that the average soil from the salt site centers may well be saline $\left(\mathrm{EC}=585 \mathrm{mS} \cdot \mathrm{m}^{-1}\right)$; however, we used the EC meter in the field simply as a means of characterizing the extent of the salt-affected area (Rhoades et al. 1999) rather than as an absolute test of soil salinity. Exchangeable $\mathrm{Na}^{+}$concentrations were significantly elevated in the salt sites compared with the controls when averaged across all 27 sites (Fig. 1). This effect of salt applications on mineral soil exchangeable sodium was consistent at each of the sites (Fig. 2). Calcium concentrations varied between sites and salt sites had a significant reduction in $\mathrm{Ca}^{2+}$ concentration when averaged across all 27 sites (Fig. 1). Although cation concentrations were significantly altered in the salt site centers, the concentrations are not out of the range for plant growth (Richards 1954). The significantly lower $\mathrm{Ca}^{2+}$ levels are due to the introduction of excess $\mathrm{Na}^{+}$that displaces cations from exchange sites through mass action, leading to the leaching of $\mathrm{Ca}^{2+}$ (Fig. 1).

Although SAR values were found to be significantly higher on salt sites than controls, only three of the 27 sites measured had SAR values greater than 13 and could be classified as sodic (Rhoades et al. 1999; Table 2). The relatively low SAR values are a result of animal consumption of $\mathrm{Na}^{+}$and leaching of $\mathrm{Na}^{+}$ to depth in the soil profile (Jones and Hanson 1985). The SAR values observed on most sites demonstrate $\mathrm{Na}^{+}$concentrations

Table 2. Average $\mathrm{pH}$, electrical conductivity, organic matter concentration, bulk density, and sodium absorption ratio (SAR) on site centers and controls on salt-affected sites in the Teton Wilderness. The number in parentheses represents one standard error $(n=27)$ and the $P$ value was calculated using a paired $t$ test.

\begin{tabular}{lccl}
\hline \multicolumn{1}{c}{ Variable } & Salt site center & Control & \multicolumn{1}{c}{$P$ value } \\
\hline Electrical conductance $(\mathrm{mS} / \mathrm{m})^{1}$ & $39(8.0)$ & $10(2.0)$ & $0.0032^{* * 2}$ \\
Soil pH & $4.98(0.09)$ & $4.81(0.08)$ & $0.0184^{* *}$ \\
Organic matter $\left(\mathrm{g} \mathrm{kg}^{-1}\right)$ & $7.88(2.25)$ & $12.5(1.53)$ & $0.0015^{* *}$ \\
Bulk density $\left(\mathrm{g} / \mathrm{cm}^{3}\right)$ & $1.16(0.05)$ & $0.82(0.04)$ & $0.0000^{* * *}$ \\
SAR & $10.4(4.30)$ & $0.48(0.13)$ & $0.0274^{*}$ \\
\hline
\end{tabular}

${ }^{1}$ Electrical conductance field tested in a 10:1 (v/v) water:soil slurry, multiply by 15 to approximate electrical conductivity in a saturated paste.

$2 *{ }^{* \star},{ }^{* * *}$ denote significantly different from control, at $P<0.05,0.01$, and 0.001 , respectively 


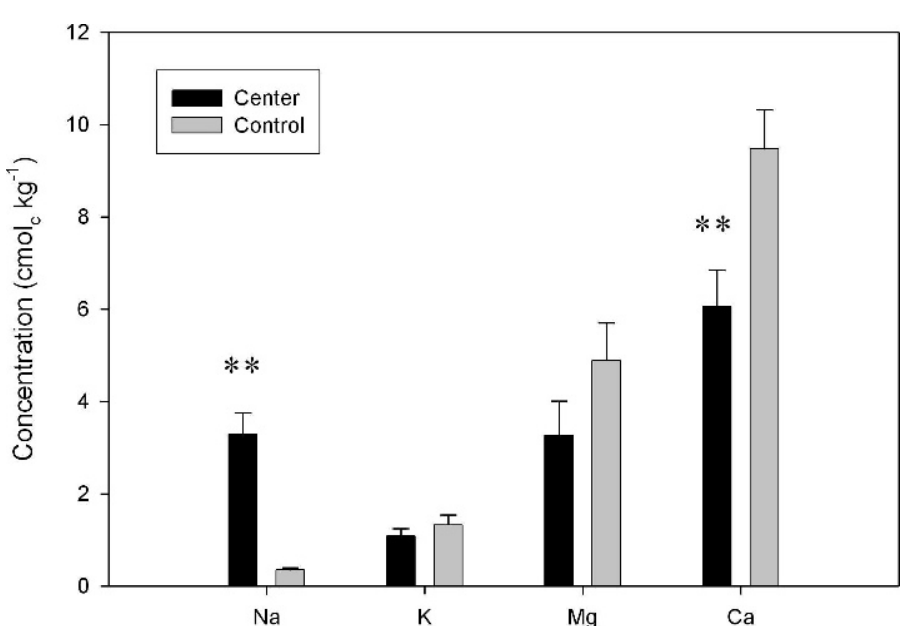

Figure 1. Average concentration of exchangeable alkaline metals in the salt site center and in the no-salt control area for 27 salt-lickaffected sites in the Teton Wilderness Area. Bars represent one standard error $(n=27)$. ${ }^{* *}$ indicates significantly different than the control at $P<0.01$.

well in excess of what occurs at undisturbed sites and will potentially have a long-term impact on the type and degree of vegetation establishment.

Organic matter was significantly lower on the salt sites compared to controls. As $\mathrm{Na}^{+}$is placed on the soil and reacts with the organic components, ungulates eat that reactive soil portion causing a loss of organic material and exposure of the mineral layers underneath (Jones and Hanson 1985). Additionally, the lack of vegetation on salt sites leads to a net loss of organic matter with time as a result of net carbon mineralization without reintroduction of plant-derived organic materials (Busse et al. 1996). Organic materials promote many positive soil characteristics such as increased cation exchange capacity, water-holding capacity, formation of stable aggregates, and stimulation of microbial activity (Logan 1992; Barker et al. 2000). This loss of soil organic matter would only further impede recovery of the salt-affected sites.

A significant increase in soil bulk density was observed on salt-affected sites (Table 2). This increase in bulk density is likely a result of the repeated trampling and compaction by ungulates and the lack of vegetation establishment on salt sites. Soil compaction specifically refers to the removal of void space and primarily the loss of macropores. Soil macropores are extremely important for water infiltration and percolation in the soil profile. Further, the loss of soil macropores reflects reduced soil aggregate stability and decreased root elongation potential (Greene et al. 1994). Trampling and soil compaction lessen the potential for plant reestablishment and thus hinder the capacity of plant establishment to restore natural soil conditions. Plant establishment would increase soil organic matter, help aerate the compacted portion of the soil, aid in the formation of aggregates, and allow for water movement and leaching of excess salt (Greene et al. 1994). The continued presence of animals on these sites combined with high sodicity, and lack of organic matter incorporation creates a selfperpetuating condition not conducive to plant growth or soil recovery.

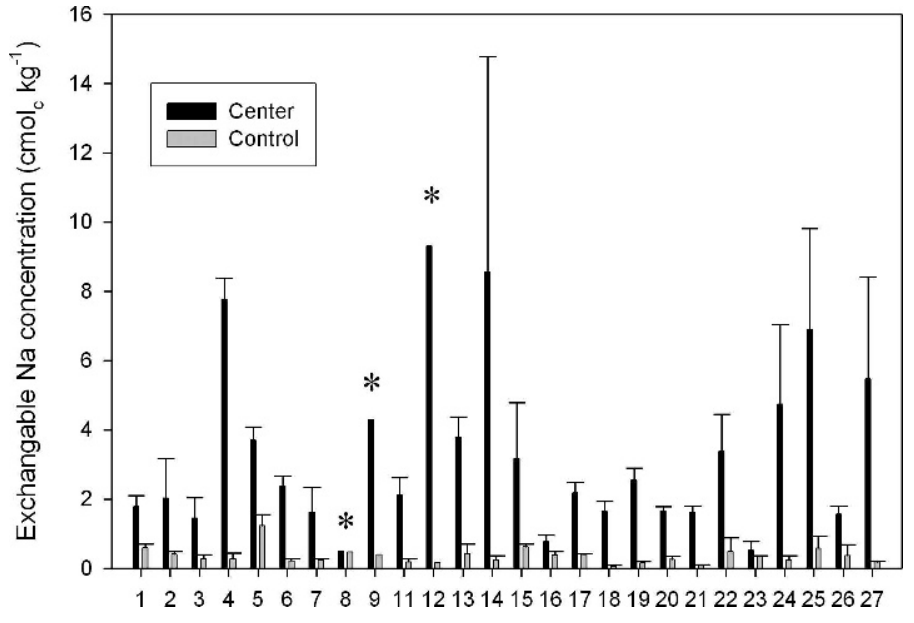

Figure 2. Average exchangeable sodium concentration for salt site center and in the no-salt control area for each of the 27 salt-lick-affected sites in the Teton Wilderness Area. Bars represent one standard error $(n=3)$ except where noted with an * next to the site number, which indicates only one observation.

\section{MANAGEMENT IMPLICATIONS}

The application of salt blocks to attract elk has resulted in the degradation of discrete soil polygons across alpine and subalpine meadows in the Teton Wilderness Area. Salt licks slowly contribute salinity and sodium to surface soils and result in heavy use of localized areas by grazing ungulates. The repeated trampling by elk and other large ungulates appears to be an important factor inhibiting plant growth on the sites studied. Past experience by game managers has shown that animals become habituated to salt sites and simply applying nutrients and seeding alone does not deter animal use. Restoration of salt-affected sites will be accelerated by eliminating salting, scarification of soils, the addition of $\mathrm{Ca}^{2+}$ and organic materials, and physical deterrents such as fencing or piling of tree limbs on salt sites. Calcium additions will help displace $\mathrm{Na}^{+}$from soil exchange sites and encourage flocculation of clays. Organic material will improve the potential for formation of water stable aggregates and macroporosity, all contributing to vegetative recovery. Restoration of these scars is important to maintain the natural condition of soils and vegetation on wilderness lands and to act as a deterrent for future or continued salt applications to these landscapes.

\section{ACKNOWLEDGMENTS}

The authors wish to thank Linda Merligiano for her extensive assistance on this project. We also thank Rob St John, Cavan Fitzsimmons, and Mark Rodgers for their assistance with logistics and site selection. This work was supported by a USFS challenge cost share agreement with the Bridger-Teton National Forest (CS-11040306) and is a contribution of the Montana Forest Experiment Station.

\section{LITERATURE CITED}

Barker, A. V., M. L. Stratton, and J. E. Rechcigl. 2000. Soil and by-product characteristics that impact the beneficial use of by products. In: J. F. Power and 
W. A. Dick [EDS.]. Land Applications of Agricultural, Industrial, and Municipal ByProducts. Madison, WI: Soil Science Society of America. p. 169-214.

Barzegar, A. R., J. M. Oades, and P. Rengasamy. 1996. Soil structure degradation and mellowing of compacted soils by saline-sodic solutions. Soil Science Society of America Journal 60:583-588.

Bresler, E., B. L. McNeal, and D. L. Carter. 1982. Saline and sodic soils: Principalsdynamics-modeling. New York: Springer-Verlag. 236 p.

Busse, M. D., P. H. Cochran, and J. W. Barrett. 1996. Changes in ponderosa pine following removal of understory vegetation. Soil Science Society America Journal 60:1614-1621.

Culley, J. L. B. 1993. Density and compressibility. In: M. L. Carter [ed.]. Soil sampling and methods of analysis. Boca Raton, FL: Lewis Publishers. p. 529-541.

Greene, R. S. B., P. I. A. Kinnell, And J. T. Wood. 1994. Role of plant cover and stock trampling on runoff and soil erosion from semi-arid wooded rangelands. Australian Journal of Soil Resources 32:953-973.

Janzen, H. H. 1993. Soluble salts. In: M. R. Carter [ED.]. Soil sampling and methods of analysis. Boca Raton, FL: Lewis Publishers. p. 161-167.

Jones, R., AND H. Hanson. 1985. Mineral licks, geophagy, and biogeochemistry of North American ungulates. Ames, IA: Iowa State University Press. 301 p.

Juniper, S., And L. K. Аввотt. 2006. Soil salinity delays germination and limits growth of hyphae from propagules of arbuscular mycorrhizal fungi. Mycorrhiza 16:371-379.

Kalra, Y. P., and D. G. Manynard. 1991. Methods manual for forest soil and plant analysis: Information. Report NOR-X-319. Edmonton, Canada: Forestry Canada, Northwest Region, Northern Forestry Centre. 116 p.
Logan, T. J. 1992. Reclamation of chemically degraded soils. In: R. Lal and B. A. Stewart [EDS.]. Soil restoration. New York, NY: Springer-Verlag. p. 161-167.

RHOADES, J. D. 1996. Salinity: electrical conductivity and total dissolved solids. In: D. L. Sparks [ED.]. Methods of soil analysis. Madison, WI: American Society of Agronomy. p. 417-435.

Rhoades, J. D., F. Chanduvi, and S. Leech. 1999. Soil salinity assessment methods and interpretation of electrical conductivity measurements. FAO Irrigation and Drainage Paper 57. Rome: Food and Agriculture Organization of the United Nations. 152 p.

RICHARDS, L. E. 1954. Diagnosis and improvement of saline and alkali soils. US Salinity Laboratory. Riverside, CA: United States Department of Agriculture. $160 \mathrm{p}$.

SoKal, R., AND F. RohlF. 1981. Biometry: The principles and practice of statistics in biological research. New York, NY: W. H. Freeman and Company. 859 p.

Sonnevelt, C., And J. van der Ende. 1971. Soil analysis by a 2:1 volume extract. Plant and Soil 35:505-516.

ThomAs, G. W. 1996. Soil pH and soil acidity. In: D. L. Sparks [ED.]. Methods of soil analysis: Part 3, chemical methods. Madison, WI: American Society of Agronomy. p. 475-490.

WeEks, H. 1974. Physiological, morphological, and behavioral adaptations of wild herbivorous mammals to a sodium-deficient environment [dissertation]. West Lafayette, IN: Purdue University. $421 \mathrm{p}$.

Zahow, M. F., AND C. AmrHein. 1992. Reclamation of saline sodic soil using synthetic polymers and gypsum. Soil Science Society of America Journal $56: 1257-1260$. 